\title{
GURU: PROFESI YANG TAK LEKANG OLEH WAKTU ${ }^{1}$ \\ Oleh: \\ Zulhafizh, S.Pd., M.Pd. ${ }^{2}$ \\ Email: zulhafizhss@gmail.com
}

\author{
Anda telah memasuki wilayah baru \\ Anda beruntung hadir dan berada di ruangan ini \\ Karena Anda akan menemukan hal-hal yang tak disangka, tak terduga \\ Jadilah guru generasi baru \\ Yang akan merubah dan meneruskan perjuangan guru \\ Yang belum jua rampung, belum jua selesai
}

\section{Pengantar}

Ada hal ingin disampaikan pada kertas kerja ini, sesungguhnya ini sebuah renungan yang tiada ujung dan entah di mana pangkalnya. Masih teringat 8 tahun yang lalu, sebagai seorang yang pernah mengecap pendidikan formal selayaknya orang-orang diperkotaan, saya juga punya harapan dan impian ke depannya. Sedikit meminjam prakata dalam cerita Malin Kundang "Ingin merubah nasib". Ungkapan ini tentu saja menyiratkan suatu hal, ada tujuan yang hendak dicapai. Suatu ketika, beberapa anak sempat ditanya oleh salah satu gurunya. Seperti biasa, pertanyaan untuk anak-anak sekolah umumnya berkaitan dengan cita-cita, diantara mereka satu pun tidak ada yang memberikan jawaban bahwa ia ingin jadi guru. Sangat beragam jawaban yang mereka berikan kepada gurunya, saya ingin jadi pilot, perawat, bidan, polisi, arsetik dan sebagainya, itulah jawaban mereka. Saat itu, saya sendiri pun tidak memberikan jawaban tentang keinginan saya menjadi guru (pendidik). Namun takdir berkata lain, saya dipertemukan dengan profesi yang sangat membanggakan, yaitu guru.

Dulu, saya termasuk orang yang sempat meremehkan profesi guru dan menganggap guru adalah profesi pilihan terakhir, karena dulu memang belum menemukan makna guru yang sebenarnya. Sejak kecil saya tidak pernah punya

${ }^{1}$ Kertas kerja ini dibentangkan dalam kegiatan Dialog Interaktif Profesi Kependidikan, yang dilaksanakan pada hari Sabtu, 15 Juni 2013, di Aula FKIP Universitas Islam Riau-Pekanbaru.

2 Penulis, alumni Universitas Riau (S1) dan Universitas Negeri Padang (S2). 
cita-cita menjadi guru. Saya justru lebih memilih profesi selain guru. Tapi, semuanya berkata lain. Guru adalah profesi yang sangat membanggakan. Bagaimana tidak, Indonesia, bangsa kita terlahir karena jasa para guru. Guru adalah orang yang diteladani dan dimuliakan karena jasa dan ilmunya. Sungguh sangat ironis jika profesi ini dikucilkan banyak orang, semestinya ia harus dicintai dan dibanggakan.

Saya ingin Saudara berpikir ke belakang dan berusaha memahaminya. Masih ingat bagaimana perjuangan pendidikan di negara kita. Yang paling berjasa saat itu adalah guru. Kenapa? Beberapa pejuang saat itu, terlahir karena didikan para guru. Pejabat pemerintah baik swasta maupun negeri juga terlahir karena didikan para guru. Ini menandakan bahwa guru penting adanya, dan profesi ini sesungguhnya tidak pernah lekang oleh waktu. Tiada guru, sama siapa kita bertanya.

Sebuah ungkapan bijak, 'Kalau ingin melihat kualitas suatu bangsa, lihatlah kualitas gurunya'. Artinya keberadaan guru di sini sangat menentukan kualitas suatu bangsa, dan kualitas suatu bangsa bisa dilihat dari mutu. Peningkatan mutu bermuara pada pendidikan. Pendidikan tidak bisa terlepas dari peran guru. Guru merupakan ujung tombak dalam proses pendidikan. Maka tidaklah keliru, jika dikatakan guru sebagai pengajar (mentransformasi pengetahuan yang dimilikinya kepada peserta didik, pada batasan ini hanya pada tataran mentransfer pengetahuan), guru sebagai pendidik (berusaha menanamkan nilai-nilai luhur kepada peserta didik), dan guru sebagai pemimpin (tahapan ini guru tidak hanya melakukan pengajaran dan pendidikan tapi berusaha menciptakan iklim pembelajaran yang kondusif dan dapat berkomunikasi dengan orang tua sebagai bentuk tanggung jawabnya).

Keberadaan guru tidak pernah lekang dari waktu, sampai kapan pun kita tetap membutuhkannya. Profesi guru sangat diperlukan kehadirannya dalam setiap saat. Apa bila kita terkendala dan tidak mengetahui akan sesuatu, ke mana harus bertanya? Jawabannya adalah guru. Pada bagian ini, saya ingin menegaskan 
bahwasanya "Banggalah Saudara sebagai calon guru (pendidik), karena Saudara akan disanjung dan diharapkan kehadirannya dalam setiap saat”. Kalimat ini diharapkan dapat menuntun Saudara menjadi guru/pendidik yang handal. Terjunlah secara utuh, menjadi guru yang diharapkan, menghantarkan anak-anak ke pelataran yang cemerlang. Berdasarkan uraian tersebut, tulisan ini berupaya memberikan gambaran umum tentang profesi guru.

\section{Ada Apa dengan Guru?}

Guru sangat penting dalam peradaban manusia. Guru menjadi pencetak generasi penerus umat manusia.Guru dalam bahasa Indonesia merujuk pendidik profesional dengan tugas utamanya adalah mendidik, mengajar, membimbing, mengarahkan, melatih, menilai, dan mengevaluasi peserta didik. Guru juga dapat diartikan dengan digugu dan ditiru setiap ucapan, tindakan ataupun tingkah lakunya sebagai suatu pedoman atau penuntun pada setiap peserta didik, baik di lingkungan sekolah ataupun di lingkungan keluarga dan juga masyarakat.

Guru adalah orang yang mampu memberikan pencerahan dan juga pemahaman baik moral maupun sprirtual kepada setiap insan. Guru adalah pendidik dan mengajari seseorang baik di jalur sekolah atau pendidikan formal, pendidikan dasar, dan pendidikan menengah. Perlu diketahui dan dipahami, bahwasanya guru yang mengajar dengan asal-asalan dan tidak profesional, beresiko menghasilkan generasi penerus yang rusak dan selanjutnya akan menghancurkan peradaban masyarakat. Maka dari itu, guru yang profesional mutlak diperlukan.

Guru menjadi ujung tombak dalam segala hal, dalam segala bidang. Kenapa demikian? Apapun harapan yang hendak digapai, seseorang mesti melalui beberapa tahapan untuk mencapainya. Tahapan itu adalah belajar, bertanya, dan berguru. Di sinilah letak peranan guru. Ia sebagai pencerah dan pengarah untuk mencapai yang diinginkannya. Maka, kehadiran guru mutlak diperlukan, kapan dan di mana saja. Ia sebagai penerang ketika gelap. Untuk menjadi yang demikian, jadilah guru secara utuh (kaffah), yang profesional. Hasibuan 
menjelaskan bahwa guru sebagai pemegang kunci (key person) sangat menentukan proses keberhasilan peserta didiknya (http://www.psychologymania. com/2012/12/kompetensi-profesional-guru.html).

\section{Menjadi Guru Profesional}

Sesuai dengan fungsinya, guru tidak hanya menyampaikan materi ajar saja, tetapi harus melakukan tindakan mendidik. Oleh karena itu, guru perlu memiliki kemampuan memotivasi belajar, memahami potensi peserta didik, sehingga mampu memberikan pelayanan yang optimal. Apalagi dalam era globalisasi komunikasi seperti saat ini perlu adanya perubahan orientasi di dalam proses pembelajaran.

Daryanto (2009) menjelaskan bahwa guru bukanlah satu-satunya sumber informasi, tapi guru berfungsi sebagai fasilitator, motivator, dan membantu peserta didik dalam berbagai hal yang dialaminya. Perubahan peran dan fungsi guru di dalam proses pembelajaran tersebut menuntut adanya perubahan dan peningkatan kompetensi profesional guru. Menurut Syah (2009) menjelaskan bahwa kompetensi adalah suatu kemampuan, kecakapan, keadaan berwenang, atau memenuhi syarat menurut ketentuan hukum. Selanjutnya dikemukakan bahwa kompetensi guru adalah kemampuan seorang guru dalam melaksanakan kewajiban-kewajibannya secara bertanggung jawab dan layak. Jadi kompetensi profesional guru dapat dimaknai sebagai kemampuan dan kewenangan dalam menjalankan profesi keguruannya. Guru yang kompenten dan profesional adalah guru yang piawai dalam melaksanakan profesinya. Kompetensi merupakan kebulatan penguasaan pengetahuan, keterampilan, dan sikap yang ditampilkan melalui unjuk kerja.

Permendiknas nomor 7 tahun 2010 menyebutkan bahwa kompetensi adalah seperangkat pengetahuan, keterampilan, dan perilaku yang harus dimiliki, dihayati, dan dikuasai oleh guru dalam melaksanakan tugas keprofesionalan. Selanjutnya dijelaskan bahwa kompetensi guru tersebut meliputi kompetensi kepribadian, pedagogik, profesional, dan sosial. 
1. Kompetensi Pedagogik

Kompetensi pedagogik adalah kompetensi yang berhubungan dengan tugas-tugas pendidikan dan keguruan. Kompetensi ini terdiri atas:

a. Menguasai karakteristik peserta didik dari aspek fisik, moral, sosial, kultural, emosional, dan intelektual.

b. Menguasai teori belajar dan prinsip-prinsip pembelajaran yang mendidik.

c. Mengembangkan kurikulum yang terkait dengan bidang pengembangan yang diampu.

d. Menyelenggarakan kegiatan pengembangan yang mendidik.

e. Memanfaatkan teknologi informasi dan komunikasi untuk kepentingan penyelenggaraan kegiatan pengembangan yang mendidik.

f. Memfasilitasi pengembangan potensi peserta didik untuk mengaktualisasikan berbagai potensi yang dimiliki.

g. Berkomunikasi secara efektif, empatik, dan santun dengan peserta didik.

h. Menyelenggarakan penilaian dan evaluasi proses dan hasil belajar.

i. Memanfaatkan hasil penilaian dan evaluasi untuk kepentingan pembelajaran.

j. Melakukan tindakan reflektif untuk peningkatan kualitas pembelajaran.

\section{Kompetensi Kepribadian}

Kompetensi kepribadian merupakan kompetensi personal seorang guru. Kompetensi ini merupakan sosok kepribadian seorang guru yang berkarakter sebagai orang Indonesia serta pribadi yang ideal dari orang yang menjadi teladan di masyarakat. Guru merupakan pribadi yang dapat menjadi contoh bagi yang lain. Kompetensi kepribadian guru itu terdiri atas:

a. Bertindak sesuai dengan norma agama, hukum, sosial, dan kebudayaan nasional Indonesia.

b. Menampilkan diri sebagai pribadi yang jujur, berakhlak mulia, dan teladan bagi peserta didik dan masyarakat.

c. Menampilkan diri sebagai pribadi yang mantap, stabil, dewasa, arif, dan berwibawa. 
d. Menunjukkan etos kerja, tanggungjawab yang tinggi, rasa bangga menjadi guru, dan rasa percaya diri.

e. Menjunjung tinggi kode etik profesi guru.

\section{Kompetensi Sosial}

Kompetensi sosial merupakan kompetensi guru dalam berhubungan dengan pihak lain. Dalam lingkungan masyarakat, biasanya guru menjadi contoh bagi profesi lain dalam berinteraksi dan berkomunikasi yang baik. Kompetensi sosial ini terdiri atas:

a. Bersikap inklusif (diperhitungkan), bertindak objektif, serta tidak diskriminatif karena pertimbangan jenis kelamin, agama, ras, kondisi fisik, latar belakang keluarga, dan status sosial ekonomi.

b. Berkomunikasi secara efektif, empatik, dan santun dengan sesama pendidik, tenaga kependidikan, orang tua, dan masyarakat.

c. Beradaptasi di tempat bertugas di seluruh wilayah Republik Indonesia yang memiliki keragaman sosial budaya.

d. Berkomunikasi dengan komunitas profesi sendiri dan profesi lain secara lisan dan tulisan atau bentuk lain.

\section{Kompetensi Profesional}

Kompetensi profesional merupakan kompetensi yang berhubungan dengan bidang akademik. Kompetensi ini terdiri atas:

a. Menguasai materi, struktur, konsep dan pola pikir keilmuan yang mendukung mata pelajaran yang diampu.

b. Menguasai standar kompetensi dan kompetensi dasar mata pelajaran/bidang pengembangan yang diampu.

c. Mengembangkan materi pembelajaran yang diampu secara kreatif.

d. Mengembangkan keprofesionalan secara berkelanjutan dengan melakukan tindakan reflektif.

e. Memanfaatkan teknologi informasi dan komunikasi untuk berkomunikasi dan mengembangkan diri. 
Kusmana menjelaskan bahwa keempat kompetensi profesi guru ini merupakan indikator bagi seorang guru profesional. Implementasi dari keempat komptensi ini dapat terwujud dalam aktivitas sehari-hari seorang guru, baik ketika ia sedang bertugas mendidik peserta didik dalam kelas maupun ketika ia berada di lingkungan masyarakat. Kompetensi profesi guru ini melekat dengan pribadi guru sehingga akan selalu merupakan karakter sebagai seorang pendidik yang berada di lingkungan masyarakat.

Kompetensi profesionalitas guru sangat diperlukan guna mengembangkan kualitas dan aktivitas tenaga kependidikan, dalam hal ini guru. Guru merupakan faktor penentu mutu pendidikan dan keberhasilan pendidikan. Oleh karena itu keberadaan dan peranan guru dalam perjalanan pendidikan sangat diperlukan guna meningkatkan martabat dan harapan bangsa. Daryanto (2009) menjelaskan bahwa keberadaan guru yang profesional merupakan syarat mutlak hadirnya sistem dan praktik pendidikan yang berkualitas, hampir semua bangsa di dunia ini selalu mengembangkan kebijakan yang mendorong keberadaan guru yang berkualitas. Pearson (2009) mengingat bahwa dalam proses pembelajaran, seorang guru jangan pernah mengintemidasi peserta didik, karena dapat mengganggu proses belajar peserta didik.

\section{Guru yang Baik}

Pada bagian ini, perlu disampaikan beberapa karakteristik guru yang baik. Guru yang baik pada suatu tingkat tertentu mungkin tidak sama baik pada tingkat yang lain, hal ini disebabkan oleh adanya perbedaan-perbedaan tingkat perkembangan mental dan emosional peserta didik. Dengan kata lain para peserta didik bisa saja memiliki respons yang berbeda-beda terhadap pola-pola prilaku guru yang sama.

Hamalik (2009) menjelaskan bahwa ada beberapa karakteristik atau sifatsifat guru yang baik dalam pandangan peserta didik yaitu: (1) demokratis, (2) suka bekerja sama (kooperatif), (3) baik hati, (4) sabar, (5) adil, (6) konsisten, (7) bersifat terbuka, (8) suka menolong, (9) ramah tamah, (10) suka humor, (11) 
memiliki bermacam ragam minat, (12) menguasai bahan pelajaran, (13) fleksibel, (14) menaruh minat yang maik terhadap peserta didik.

\section{Penutup}

Pekerjaan guru adalah pekerjaan profesional, artinya pekerjaan ini tidak dapat dilakukan oleh pendidik yang ditemukan sedapatnya, dengan pengetahuan sekadarnya, dipekerjakan sebisanya, yang mengajar sekenanya, serta dengan pengetahuan seadanya. Pekerjaan guru dilandasi oleh penguasaan ilmu, keterampilan, tanggung jawab, otonomi dalam mengambil keputusan pedagogis, serta kode etik sebagai pedoman bertindak.

Guru tidak pernah lekang oleh waktu, karena kehadirannya sangat diperlukan setiap saat dalam upaya dan segala hal. Sesungguhnya terlahirnya Indonesia dan kita hari ini, itu semua tidak terlepas dari jasa para guru. Berbanggalah jadi guru.

\section{Daftar Rujukan}

Clare, Omal. (tt). Apa yang Membuat Guru yang Baik: Ide Terbaik untuk Peningkatan Pendidikan Datang dari Para Pendidik Sendiri!. Dari http://www.idp-europe.org/eenet-asia/eenet-asia-9-ID/page8.php $(14 / 06 / 2015)$

Daryanto. (2009). Panduan Proses Pembelajaran. Surabaya: Cerdas Pustaka.

Jalal, Fasli, Dedi Supriadi, (2001). Reformasi Pendidikan dalam Konteks Otonomi Daerah. Jakarta: Depdiknas-Bappenas-Adicita Karya Nusa.

Hamalik, Oemar. (2009). Psikologi Belajar \& Mengajar. Bandung: Sinar Baru Algesindo.

Hasibuan. (tt). Kompetensi Profesional Guru. Dari http://www.psychologymania.com/2012/12/kompetensi-profesionalguru.html (14/06/2013)

Kusmana, Suherli. (tt) Guru Profesional dalam Pengembangan Karakter. Dari http://suherlicentre.blogspot.com/2011/02/guru-profesionaldalam-pengembangan.html (14/06/2015) 
Permendiknas nomor 7 tahun 2010 tentang Pemenuhan Kebutuhan, Peningkatan Profesionalisme, dan Peningkatan Kesejahteraan Guru, Kepala Sekolah/Madrasah, dan Pengawas.

Parsons, Les. (2009). Bullied Teacher Bullied Student. Jakarta: Grasindo.

Santrock, John W. (2008). Psikologi Pendidikan (Edisi Kedua). Jakarta: Kencana.

Syah, Muhibbin. (2009). Psikologi Belajar. Jakarta: Rajawali.

Syamdani. (2011). Menjadi Guru: 45 Kompetensi yang Harus Dimiliki Guru Profesional. Jakarta Selatan: Teras. 


\section{GURU}

PROFESI YANG TAK LEKANG OLEH WAKTU

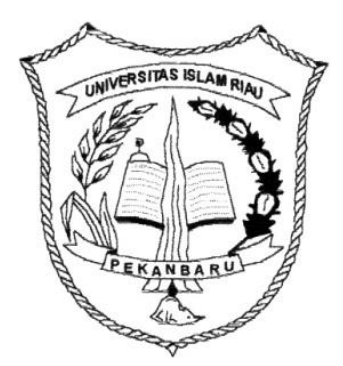

Oleh:

Zulhafizh, S.Pd., M.Pd.

FAKULTAS KEGURUAN DAN ILMU PENDIDIKAN UNIVERSITAS ISLAM 
2013 